\title{
Chemical evaluation of donkey milk yoghurt mixed with milk from different animal species
}

\author{
Rhaabe Dayane da Silva GOMES ${ }^{1}$, Maria de Fátima BEZERRA ${ }^{1}$, Cláudia Souza MACÊDO ${ }^{1}$, \\ Ingrid Laíse Silvestre de OLIVEIRA ${ }^{1}$, Luís Henrique Fernandes BORBA ${ }^{1}$, Stela Antas URBANO ${ }^{1}$, \\ Katya ANAYA ${ }^{2}$, Bruna Maria Emerenciano CHAGAS ${ }^{3}$, Júlio César de ANDRADE NETO ${ }^{1}$, \\ Juliana Paula Felipe de OLIVEIRA ${ }^{4 \star}$ (D), Adriano Henrique do Nascimento RANGEL ${ }^{1}$
}

\begin{abstract}
The objective of this study was to prepare three donkey milk yoghurt formulations mixed with goat, cow and buffalo milk. The formulations were developed with 50\% donkey milk and 50\% cow, buffalo or goat milk. Concentrated mango pulp was added for flavouring. An evaluation was performed on the chemical composition of each milk sample and the formulated yoghurts. The donkey milk showed the lowest values for fat, protein, casein, total solids and non-fat solids. In turn, goat milk reached higher levels of fat and total solids. Furthermore, buffalo milk stood out with the highest values of protein and non-fat solids. Yoghurt made with donkey and buffalo milk showed higher concentrations of protein, lactose, total solids and non-fat solids. In contrast, the yoghurt that contained donkey and cow milk in its formulation obtained a higher fat percentage and a lower percentage of lactose, total solids and non-fat solids. The low content of fat and total solids in donkey milk, in addition to the structure of the casein micelles and small fat globules favor low consistency in fermented products. Thus, mixing donkey milk with milks from other animal species can result in better chemical composition and better consistency.
\end{abstract}

Keywords: chemical composition; dairy products; Equus asinus; fermented products.

Practical Application: Use of donkey milk as a source of bioactive compounds for adding value to food products, especially dairy such as yoghurt.

\section{Introduction}

Donkey milk contains nutritional characteristics such as a low concentration of proteins and caseins and high lactose content makes it similar to human milk and enables consumption by children who are allergic to cow's milk protein (Altomonte et al., 2019; Cavallarin et al., 2015; Martini et al., 2018a; Rangel et al., 2015). In addition is recognized as hypoallergenic, with functional and nutraceutical properties (Li et al., 2020; Martini et al., 2018a; Martini et al., 2019; Souroullas et al., 2018). Donkey milk also has antioxidant and antimicrobial activity, high levels of vitamin $\mathrm{D}$ and its intake can strengthen the immune system, as well as regulate intestinal flora (Brumini et al., 2016; Lionetti et al., 2012; Martini et al., 2018b).

Such qualities make it possible to consume it directly (supplemented with vegetable oil due to its low fat content) or as an ingredient in baby food formulations (Altomonte et al., 2019; Coscia et al., 2018; Souroullas et al., 2018). Its low concentration of fat can be attractive to consumers who follow low-calorie diets such as older adults (Cavallarin et al., 2015; Salimei \& Fantuz, 2012). Thus, the development of new versions of already traditional products on the market such as fermented dairy products made or enriched with donkey milk can represent a good opportunity for popularization and consumption of this type of milk. Furthermore, these new products could create opportunities for donkey husbandry, which has become idle due to the mechanization of the agricultural sector (Carneiro et al, 2018).

However, the low content of fat and total solids in donkey milk, in addition to the structure of the casein micelles and small fat globules favor forming fragile clots and low consistency in fermented products, which, in addition to the unfamiliar flavor, can restrict acceptability (Salimei \& Fantuz, 2012; Turchi et al., 2017), despite the higher digestibility of donkey milk in comparison to cow milk (Martini et al., 2018a).

Thus, mixing donkey milk with milks from other animal species can result in good sensory acceptance and better consistency, as observed in yoghurts and fermented milks made with goat milk mixed with cow (Serhan et al., 2016) and buffalo milk (Bezerra et al., 2012), which enable a firmer clot formation due to the presence of fat globules and larger casein micelles when 
compared to goat milk (Khedkar et al., 2016; Silanikove et al., 2010; Vargas et al., 2008).

In view of this, the present work aimed to produce yoghurts from donkey milk mixed with species of cow, buffalo and caprine milks, fermented by mixed culture of Lactobacilus delbrueckii subsp. bulgaricus and Streptococcus salivarius subsp. Termophilus and flavored with concentrated mango pulp and to chemically characterize the formulations.

\section{Materials and methods}

\subsection{Obtaining the milks}

Milk from the Asinina species (Nordestina breed) was purchased from a commercial farm in the municipality of Felipe Guerra, State of Rio Grande do Norte (RN). Buffalo milk was purchased from Tapuio Agropecuária Ltda, in the city of Taipu (RN). The cow and goat milks were obtained in the cattle and goat sector, respectively, from the Jundiaí Agricultural School (EAJ), Federal University of Rio Grande do Norte (UFRN), Macaíba, RN, Northeast of Brazil. Milk samples were identified, placed in an isothermal box containing artificial ice $\left(4\right.$ to $\left.8{ }^{\circ} \mathrm{C}\right)$ and sent to the Milk Quality Laboratory (LABOLEITE), UFRN.

\subsection{Mango pulp processing}

Mango fruit (Mangifera indica) was obtained from the orchard of the Escola Agrícola de Jundiai (EAJ-UFRN). The fruit was then washed in running water and sanitized in two sodium hypochlorite solutions. The fruit remained in the first solution (100 ppm) for $15 \mathrm{~min}$ and in the second solution (5 ppm) for $10 \mathrm{~min}$. After sanitization, the fruits were subjected to cutting to remove inappropriate parts for processing. After this procedure, the fruits were taken to a compact pulper (Itametal, Itabuna, BA, Brazil) to obtain the pulp. The extracted pulp was packed in a wrapper (model 10G56) in portions corresponding to $1 \mathrm{~kg}$ and frozen at $-15{ }^{\circ} \mathrm{C}$. The fruit concentrate was prepared by submitting the natural pulp under low heat for around 1 hour until reaching $31^{\circ} \mathrm{Brix}$. The yield was approximately 50\%.

\subsection{Yoghurt preparation}

Three formulations were prepared. The percentage of $50 \%$ (v:v) of donkey milk was defined based on the limits of donkey milk mixture which did not yielded problems during pasteurization. Samples were named DCM: 50\% donkey milk and 50\% cow milk; DBM: 50\% donkey milk and 50\% buffalo milk; and DGM: 50\% donkey milk and goat milk. After mixing the milks, sugar (8\%) was added before the pasteurization, which was conducted by subjecting the mixtures to heat treatment ( $85{ }^{\circ} \mathrm{C}$ for $15 \mathrm{~min}$ ), followed by cooling down to $45^{\circ} \mathrm{C}$ in ice bath. A mixed thermophilic culture of Lactobacilus delbrueckii subsp. bulgaricus and Streptococcus salivarius subsp. termophilus in the proportion of $0.5 \%$ of the culture in relation to the initial milk volume was used for fermentation. After inoculation, the milks were kept in a B.O.D incubator (model TE-390, Tecnal, Brazil) for 4 hours at $45^{\circ} \mathrm{C}$. The fermentation process ended when the $\mathrm{pH}$ reached 4.6. The yoghurts were removed from the B.O.D and left at room temperature for $30 \mathrm{~min}$ to stop the fermentative process. The formulations were stored in a cold chamber at a temperature of $5{ }^{\circ} \mathrm{C}$. After one day of storage, concentrated mango pulp was added to the formulations in the proportion of $15 \%$ (w/w, pulp/yoghurt). The addition was manually performed in order to achieve homogeneity in the mixture. The production flowchart is shown in Figure 1 adapted from Ferreira (2005) and Ordóñez (2005).

\subsection{Chemical evaluation of the milks and yoghurts}

Donkey, cow, buffalo and goat milk samples were subjected to chemical composition, fat, total protein, lactose, casein, total solids (TS) and non-fat solids (NFS) were evaluated electronic analysis by infrared absorption in a DairySpec ${ }^{\circledast}$ FT instrument (Bentley Instruments Inc., Chaska MN, USA).

The yoghurts were analyzed by the same method. Due to the viscosity of the products, a 1:1 dilution (v/v, distilled water/ yoghurt) was made before subjecting the samples to the analytical process. The yoghurts were analyzed as pasteurized milk and the results were multiplied by two after reading the samples to obtain the real proportion of the constituents. Fat, total protein, lactose, total solids (TS) and non-fat solids (NFS) were evaluated.

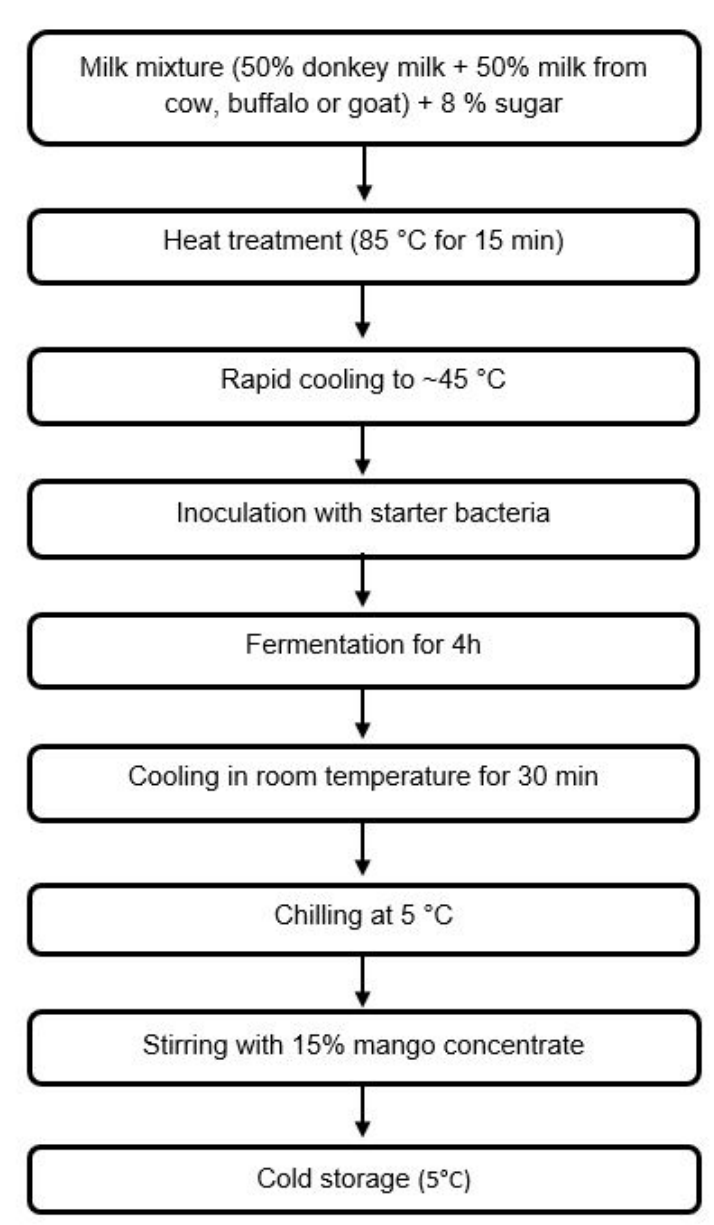

Figure 1. Processing steps in the manufacture of mango flavored stirred yogurt made with a mixture of donkey milk and milk from cow, buffalo or goat. Adapted from Ferreira (2005) and Ordóñez (2005). 


\subsection{Ethical aspects}

This protocol was registered and approved by the Research Ethics Committee of the Federal University of Rio Grande do Norte, under the registration number 76782517.0.0000.5537.

\subsection{Statistical analysis}

Data evaluation was performed by calculating the mean and standard deviation and statistical differences were assessed by analysis of variance (ANOVA) complemented by the Tukey test at 5\% significance level in the SAS program (version 9.0).

\section{Results and discussion}

\subsection{Chemical evaluation of the milks}

The results presented in Table 1 show that all milks were different from each other for the evaluated parameters $(P<$ 0.05). The donkey milk showed the lowest values for fat, protein, casein, total solids and non-fat solids, while on the other hand it presented the highest value for lactose. In turn, goat milk reached higher levels of fat and total solids. Furthermore, buffalo milk stood out with the highest values of protein and non-fat solids, and this high content of non-fat solids may have been influenced by the low amount of fat present in milk and the high protein content. Cow milk had the lowest lactose content when compared to the other milks.

The reduced fat, protein, casein, total solids and non-fat solids content in donkey milk confirms previous studies with milk from Italian farms (Cavallarin et al., 2015; Altomonte et al., 2019; Murgia et al., 2016) and may be responsible for the low yield of dairy products and reduced consistency of fermented milks (Turchi et al., 2017). While the high percentage of lactose found, common in this type of milk (Massouras et al., 2017), provides greater sweetness compared to other types of milk intended for human consumption (Dave \& Singh, 2019; Lucey, 2002; Saint-Eve et al., 2006) and may favor better palatability.

Considering that casein is an important component in structuring the three-dimensional network which forms a clot in fermented milks (Dave \& Singh, 2019; Lucey, 2002; Saint-Eve et al., 2006), the highest percentage $(P<0.05)$ of this constituent found in this study for buffalo milk can provide greater firmness and consistency in fermented dairy products. Thus, the use of buffalo milk in a mixture with donkey milk can constitute a good alternative for increasing the formation of the gel in yoghurts.

The higher percentage of fat and total solids in goat milk in relation to the other species (mainly cow and buffalo) observed in the present work is possible because the nutritional concentrations vary according to the breed of milk-producing goats, reaching higher or lower percentages, but the most important differences are component structure (Ceballos et al., 2009; Silanikove et al., 2010).

\subsection{Compositional evaluation of the yoghurts}

The differences observed for all composition parameters of the three types of yoghurts had statistical significance $(P<0.05)$ (Table 2). Yoghurt made with donkey and buffalo milk showed higher concentrations of protein, lactose, total solids and non-fat solids. In contrast, the yoghurt that contained donkey and cow milk in its formulation obtained a higher fat percentage and a lower percentage of lactose, total solids and non-fat solids. The formulation made with donkey and goat milk showed intermediate values for lactose, total solids and non-fat solids.

The addition of cow, buffalo or goat milk to donkey milk yoghurt formulations provided a higher fat, protein, lactose

Table 1. Milk composition of different species.

\begin{tabular}{ccccc}
\hline \multirow{2}{*}{ Constituents } & \multicolumn{3}{c}{ Species } \\
\cline { 2 - 5 } & Donkey & Cow & Buffalo & Goat \\
\hline Fat (\%) & $0.036^{\mathrm{d}} \pm 0.01$ & $2.95^{\mathrm{b}} \pm 0.01$ & $2.15^{\mathrm{c}} \pm 0.09$ & $3.57^{\mathrm{a}} \pm 0.03$ \\
Protein (\%) & $1.34^{\mathrm{d}} \pm 0.01$ & $3.31^{\mathrm{b}} \pm 0.01$ & $4.14^{\mathrm{a}} \pm 0.01$ & $2.86^{\mathrm{c}} \pm 0.01$ \\
Casein (\%) & $1.00^{\mathrm{d}} \pm 0.02$ & $2.57^{\mathrm{b}} \pm 0.01$ & $3.07^{\mathrm{a}} \pm 0.01$ & $2.34^{\mathrm{c}} \pm 0.01$ \\
Lactose (\%) & $5.82^{\mathrm{a}} \pm 0.02$ & $4.26^{\mathrm{d}} \pm 0.00$ & $4.50^{\mathrm{c}} \pm 0.01$ & $4.91^{\mathrm{b}} \pm 0.01$ \\
TS (\%) & $8.23^{\mathrm{d}} \pm 0.02$ & $11.41^{\mathrm{c}} \pm 0.01$ & $12.02^{\mathrm{b}} \pm 0.09$ & $12.37^{\mathrm{a}} \pm 0.04$ \\
NFS (\%) & $8.18^{\mathrm{d}} \pm 0.02$ & $8.47^{\mathrm{c}} \pm 0.04$ & $9.99^{\mathrm{a}} \pm 0.01$ & $9.53^{\mathrm{b}} \pm 0.02$ \\
\hline
\end{tabular}

Results presented as mean \pm standard deviation. Values in the same row followed by different letters means statistical difference by the Tukey test ( $<0.05)$. NFS $=$ non-fat solids; TS $=$ Total Solids

Table 2. Composition of mixed yoghurt formulations.

\begin{tabular}{cccc}
\hline \multirow{2}{*}{ Components } & \multicolumn{3}{c}{ Mixed yoghurt formulations } \\
\cline { 2 - 4 } & Donkey and cow (DCM) & Donkey and buffalo (DBM) & Donkey and goat (DGM) \\
\hline Fat (\%) & $2.09^{\mathrm{a}} \pm 0.01$ & $1.89^{\mathrm{b}} \pm 0.05$ & $1.77^{\mathrm{c}} \pm 0.04$ \\
Protein (\%) & $2.34^{\mathrm{b}} \pm 0.04$ & $2.61^{\mathrm{a}} \pm 0.01$ & $2.25^{\mathrm{c}} \pm 0.01$ \\
Lactose (\%) & $12.98^{\mathrm{c}} \pm 0.03$ & $13.71^{\mathrm{a}} \pm 0.01$ & $13.61^{\mathrm{b}} \pm 0.04$ \\
Total solids (\%) & $18.89^{\mathrm{c}} \pm 0.03$ & $19.63^{\mathrm{a}} \pm 0.06$ & $19.29^{\mathrm{b}} \pm 0.07$ \\
NFS (\%) & $16.81^{\mathrm{c}} \pm 0.04$ & $17.86^{\mathrm{a}} \pm 0.02$ & $17.39^{\mathrm{b}} \pm 0.06$
\end{tabular}

Results presented as mean \pm standard deviation. Values in the same row followed by different letters means a statistical difference by the Tukey test ( $\mathrm{p}<0.05)$. NFS $=$ Non-fat solids. 
and total solids content when we compared the results found with fermented milk made only with donkey milk developed by Tidona et al. (2015). The authors observed $0.40 \%$ fat, $1.8 \%$ protein, $5.28 \%$ lactose and $9.43 \%$ total solids. In addition, the lower content of total solids and non-fat solids in goat milk (Table 1) reflected a lower percentage of these components in yoghurt formulation DGM (Table 2).

The highest percentages $(P<0.05)$ of protein, lactose, total solids and non-fat solids observed in DBM yoghurt can favor greater consistency and improve the sensory acceptance of the product (Khedkar et al., 2016), considering that the low firmness of the fermented donkey milk clot is linked as a restricting factor for its consumption (Turchi et al., 2017). However, other studies addressing rheological behavior such as viscosity and syneresis must be carried out to understand the influence of buffalo milk mixed with donkey milk.

\section{Conclusion}

The low content of fat and total solids in donkey milk, in addition to the structure of the casein micelles and small fat globules favor forming fragile clots and low consistency in fermented products. Thus, mixing donkey milk with milks from other animal species can result in better chemical composition and better consistency, as observed in yoghurts and fermented milks made with goat milk mixed with cow and buffalo milk, which enable a firmer clot formation due to the presence of fat globules and larger casein micelles. Furthermore, the development of new versions of already traditional products on the market such as fermented dairy products made or enriched with donkey milk can represent a good opportunity for popularization and consumption of this type of milk.

\section{Acknowledgements}

The authors gratefully acknowledge the Milk Quality Laboratory, the Milk Processing Unit and the Fruit and Vegetable Processing Unit of Escola Agrícola de Jundiaí, Universidade Federal do Rio Grande do Norte, and the Coordenação de Aperfeiçoamento de Pessoal de Nível Superior (CAPES) for master's degree fellowship granted to the first author.

\section{References}

Altomonte, I., Salari, F., Licitra, R., \& Martini, M. (2019). Donkey and human milk: Insights into their compositional similarities. International Dairy Journal, 89, 111-118. http://dx.doi.org/10.1016/j. idairyj.2018.09.005.

Bezerra, M. F., Souza, D. F. S., \& Correia, R. T. P. (2012). Acidification kinetics, physicochemical properties and sensory attributes of yoghurts prepared from mixtures of goat and buffalo milks. International Journal of Dairy Technology, 65(3), 437-443. http:// dx.doi.org/10.1111/j.1471-0307.2012.00845.x.

Brumini, D., Criscione, A., Bordonaro, S., Vegarud, G. E., \& Marletta, D. (2016). Whey proteins and their antimicrobial properties in donkey milk: a brief review. Dairy Science \& Technology, 96(1), 1-14. http:// dx.doi.org/10.1007/s13594-015-0246-1.

Carneiro, G. F., Lucena, J. E. C., \& Barros, L. O. (2018). The current situation and trend of the donkey industry in South America.
Journal of Equine Veterinary Science, 65, 106-110. http://dx.doi. org/10.1016/j.jevs.2018.03.007.

Cavallarin, L., Giribaldi, M., Soto Del Rio, M. D., Valle, E., Barbarino, G., Gennero, M. S., \& Civera, T. (2015). A survey on the milk chemical and microbiological quality in dairy donkey farms located in NorthWestern Italy. Food Control, 50(1), 230-235. http://dx.doi. org/10.1016/j.foodcont.2014.08.019.

Ceballos, L. S., Morales, E. R., de la Torre Adarve, G., Castro, J. D., Martínez, L. P., \& Sampelayo, M. R. S.. (2009). Composition of goat and cow milk produced under similar conditions and analyzed by identical methodology. Journal of Food Composition and Analysis, 22(4), 322-329. http://dx.doi.org/10.1016/j.jfca.2008.10.020.

Coscia, A., Bertino, E., Tonetto, P., Peila, C., Cresi, F., Arslanoglu, S., Moro, G. E., Spada, E., Milani, S., Giribaldi, M., Antoniazzi, S. Conti, E., \& Cavallarin, L. (2018). Nutritional adequacy of a novel human milk fortifier from donkey milk in feeding preterm infants: study protocol of a randomized controlled clinical trial. Nutrition Journal, 17(1), 6. http://dx.doi.org/10.1186/s12937-017-0308-8. PMid:29316931.

Dave, A. C., \& Singh, H. (2019). Milk protein interactions. In P. Varelis, L. Melton \& F. Shahidi (Eds.), Encyclopedia of food chemistry (Vol. 2, pp. 63-69). Palmerston North: Elsevier. https://doi.org/10.1016/ B978-0-08-100596-5.22414-1.

Ferreira, C. L. L. F. (2005). Produtos lácteos fermentados: aspectos bioquímicos e tecnológicos. caderno didáticos (3th ed.). Viçosa: Editora UFV.

Khedkar, C. D., Kalyankar, S. D., \& Deosarkar, S. S. (2016) Buffalo milk. In B. Caballero, P. M. Finglas \& F. Toldrá (Eds.), Encyclopedia of food and health (pp. 522-529). Amsterdam: Elsevier. http://dx.doi. org/10.1016/B978-0-12-384947-2.00093-3.

Lionetti, L., Cavaliere, G., Bergamo, P., Trinchese, G., De Filippo, C., Gifuni, G., Gaita, M., Pignalosa, A., Donizzetti, I., Putti, R., Di Palo, R., Barletta, A., \& Mollica, M. P. (2012). Diet supplementation with donkey milk upregulates liver mitochondrial uncoupling, reduces energy efficiency and improves antioxidant and antiinflammatory defences in rats. Molecular Nutrition \& Food Research, 56(10), 15961600. http://dx.doi.org/10.1002/mnfr.201200160. PMid:22930490.

Li, Y., Fan, Y., Shaikh, A. S., Wang, Z., Wang, D., \& Tan, H. (2020). Dezhou donkey (Equus asinus) milk a potential treatment strategy for type 2 diabetes. Journal of Ethnopharmacology, 246, 112221. http://dx.doi.org/10.1016/j.jep.2019.112221. PMid:31494203.

Lucey, J. A. (2002). Formation and physical properties of milk protein gels. Journal of Dairy Science, 85(2), 281-294. http://dx.doi.org/10.3168/ jds.S0022-0302(02)74078-2. PMid:11913691.

Martini, M., Altomonte, I., Licitra, R., \& Salari, F. (2018b). Short communication: Technological and seasonal variations of vitamin D and other nutritional components in donkey milk. Journal of Dairy Science, 101(10), 8721-8725. http://dx.doi.org/10.3168/jds.201814776. PMid:30055917.

Martini, M., Altomonte, I., Licitra, R., \& Salari, F. (2018a). Nutritional and Nutraceutical Quality of Donkey Milk. Journal of Equine Veterinary Science, 65, 33-37. http://dx.doi.org/10.1016/j.jevs.2017.10.020.

Martini, M., Salari, F., Licitra, R., La Motta, C., \& Altomonte, I. (2019). Lysozyme activity in donkey milk. International Dairy Journal, 96, 98-101. http://dx.doi.org/10.1016/j.idairyj.2019.04.009.

Massouras, T., Triantaphyllopoulos, K. A., \& Theodossiou, I. (2017). Chemical composition, protein fraction and fatty acid profile of donkey milk during lactation. International Dairy Journal, 75, 8390. http://dx.doi.org/10.1016/j.idairyj.2017.06.007. 
Murgia, A., Scano, P., Contu, M., Ibba, I., Altea, M., Bussu, M., Demuru, M., Porcu, A., \& Caboni, A. (2016). Characterization of donkey milk and metabolite profile comparison with human milk and formula milk. Lebensmittel-Wissenschaft + Technologie, 74, 427-433. http:// dx.doi.org/10.1016/j.lwt.2016.07.070.

Ordóñez, J. A. (2005). Tecnologia de alimentos: alimentos de origem animal. Porto Alegre: Artmed.

Rangel, A. H. N., Galvão Jr, J. G. B., Simplício, A. A., Freire, R. M. B., Novaes, L. P. (2015). Aspectos composicionais e nutricionais do leite de jumenta: Uma revisão. Revista do Instituto de Laticínios Cândido Tostes, 70(3), 160-171. https://doi.org/10.14295/2238-6416.v70i3.395.

Saint-Eve, A., Juteau, A., Atlan, S., Martin, N., \& Souchon, I. (2006). Complex viscosity induced by protein composition variation influences the aroma release of flavored stirred yogurt. Journal of Agricultural and Food Chemistry, 54(11), 3997-4004. http://dx.doi. org/10.1021/jf0600206. PMid:16719526.

Salimei, E., \& Fantuz, E. (2012). Equid milk for human consumption. International Dairy Journal, 24(2), 130-142. http://dx.doi.org/10.1016/j. idairyj.2011.11.008.

Serhan, M., Mattar, J., \& Debs, L. (2016). Concentrated yogurt (Labneh) made of a mixture of goats' and cows' milk: Physicochemical, microbiological and sensory analysis. Small Ruminant Research, 138, 46-52. http://dx.doi.org/10.1016/j.smallrumres.2016.04.003.
Silanikove, N., Leitner, G., Merin, U., \& Prosser, C. G. (2010). Recent advances in exploiting goat's milk: Quality, safety and production aspects. Small Ruminant Research, 89(2-3), 110-124. http://dx.doi. org/10.1016/j.smallrumres.2009.12.033.

Souroullas, K., Aspri, M., \& Papademas, P. (2018). Donkey milk as a supplement in infant formula: benefits and technological challenges. Food Research International, 109, 416-425. http://dx.doi.org/10.1016/j. foodres.2018.04.051. PMid:29803466.

Tidona, F., Charfi, I., Povolo, M., Pelizzola, V., Carminati, D., Contarini, G., \& Giraffa, G. (2015). Fermented beverage emulsion based on donkey milk with sunflower oil. International Journal of Food Science \& Technology, 50(12), 2644-2652. http://dx.doi.org/10.1111/ijfs.12936.

Turchi, B., Pedonese, F., Torracca, B., Fratini, F., Mancini, S., Galiero, A., Montalbano, B., Cerri, D., \& Nuvoloni, R. (2017). Lactobacillus plantarum and Streptococcus thermophilus as starter cultures for a donkey milk fermented beverage. International Journal of Food Microbiology, 256, 54-61. http://dx.doi.org/10.1016/j.ijfoodmicro.2017.05.022. PMid:28599175.

Vargas, M., Cháfer, M., Albors, A., Chiralt, A., \& González-Martínez, C. (2008). Physicochemical and sensory characteristics of yoghurt produced from mixtures of cows' and goats' milk. International Dairy Journal, 18(12), 1146-1152. http://dx.doi.org/10.1016/j. idairyj.2008.06.007. 